\title{
Synthesis and Photodynamic Activity of 5,10,15-Tris(p-chlorophenyl)-20-(2- hydroxy-3-methoxyphenyl)-21H,23H-porphyrin
}

\author{
Eder Arredondo-Espinoza, Susana López-Cortina, Isaías Balderas-Rentería* \\ Universidad Autónoma de Nuevo León, Laboratorio de Ingeniería Genética y Genómica, Facultad de Ciencias Químicas, Av. \\ Universidad s/n, Cd. Universitaria, 66451 San Nicolás de los Garza, N.L., México. isaias.balderasrn@uanl.edu.mx.
}

Received February $10^{\text {th }}, 2014$; Accepted April 22 2014

\begin{abstract}
Photodynamic therapy (PDT) is an effective option for the treatment of solid neoplastic tumors, as well as non-malignant diseases such as dermatological, ophthalmological and benign pathologies. PDT destroys cancer cells by photochemical generation of reactive oxygen species upon absorption of visible light by a photosensitizing agent (PS). Here, we describe the synthesis and characterization of the unsymmetrical $\mathrm{A}_{3} \mathrm{~B}$ porphyrin 5,10,15-Tris(p-chlorophenyl)-20(2-hydroxy-3-methoxyphenyl)-21H,23H-porphyrin, which presents different groups at the meso positions, $p$-chlorophenyl and 2-hydroxy3 -methoxyphenyl and is a novel target molecule in order to evaluate the synergistic effect of these hydrophobic and hydrophilic moieties distributed unsymmetrically on the porphyrin macrocycle. We demonstrated the in vitro cytotoxic effect of the synthesized porphyrin, by the WST-1 assay on a cultured human cervical adenocarcinoma cell line (HeLa ATCC: CCL-2), as well as the presence of apoptosis by T.U.N.E.L. assay. We compared the phototoxicity and intrinsic cytotoxicity of the PS and found a considerable difference in the $\mathrm{IC}_{50}$ between phototoxic activity $(1.5 \mu \mathrm{M})$ and intrinsic cytotoxicity $(7$ $\mu \mathrm{M})$. The results of the induction of apoptosis on HeLa cells treated with the unsymmetrical porphyrin at a final concentration of $80 \mu \mathrm{M}$ showed $15 \%$ apoptotic cells, whereas the untreated HeLa cells had only $2.5 \%$ apoptotic cells.
\end{abstract}

Keywords: Photodynamic therapy, photosensitizer, unsymmetrical porphyrins, apoptosis, anti-cancer agents.

\section{Introduction}

Photodynamic therapy (PDT) is based on the systemic administration of photosensitizing agents (PSs), followed by selective irradiation at an appropriate wavelength. Upon excitation of the PS, which interacts with molecular oxygen to produce singlet oxygen $\left({ }^{1} \mathrm{O}_{2}\right)$ and other reactive oxygen species, PDT is attractive as cancer treatment, because it has minimal side effects due to its preferential distribution of the PSs in tumors compared with normal tissues and to the delimited light irradiation around the tumor [1-3]. Porphyrins, one of the most popular PSs, are aromatic macrocycles formed by four pyrrole rings joined together by interpyrrolic methine bridges; the macrocycle contains a total of $22 \pi$ electrons with $18 \pi$ electrons in direct conjugation. Porphyrins are interesting molecules that play key roles in many biological processes (oxygen transport, electron transfer and oxidation catalysis) [4-6].

The singlet oxygen can directly destroy tumor cells by induction of necrosis and apoptosis and it can also cause the destruction of tumor microvasculature and produce a significant inflammatory response that attracts leukocytes such as neutrophils and macrophages [7-9]. Due to the short life time
Resumen: La terapia fotodinámica (TFD) es una alternativa terapéutica efectiva en el tratamiento de tumores sólidos así como otras enfermedades benignas o de origen dermatológico u oftalmológico. La TFD elimina las células neoplásicas mediante la formación de especies reactivas de oxígeno generadas fotoquímicamente tras la absorción de luz visible por un agente fotosensibilizador. En el presente trabajo, se describe la síntesis y la caracterización de la 5,10,15-Tris( $p$-clorofenil)-20-(2-hidroxi-3-metoxifenil)-21H,23H-porfirina, porfirina no simétrica del tipo $\mathrm{A}_{3} \mathrm{~B}$ con diferentes grupos en las posiciones meso, $p$-clorofenilo y 2-hidroxi-3-metoxifenilo, obteniendo de esta forma una molécula estructuralmente novedosa para evaluar el efecto sinérgico de los grupos hidrofóbicos e hidrofílicos con una distribución no simétrica en el macrociclo de la porfirina. Se demuestra además, el efecto citotóxico in vitro mediante el ensayo de WST-1 en una línea de cáncer cervicouterino (HeLa ATCC: CCL-2), así como la inducción de apoptosis por medio del ensayo de T.U.N.E.L. Se comparó la fototoxicidad y citotoxicidad intrínseca de la porfirina no simétrica y se encontró una diferencia considerable en el $\mathrm{IC}_{50}$ entre la actividad fototóxica $(1.5 \mu \mathrm{M})$ y la citotoxicidad intrínseca $(7 \mu \mathrm{M})$. Los resultados de la inducción de la apoptosis en las células HeLa tratadas con la porfirina no simétrica a una concentración final de $80 \mu \mathrm{M}$, mostraron $15 \%$ de células apoptóticas, mientras que las células HeLa no tratadas mostraron sólo $2.5 \%$ de apoptosis.

Palabras clave: Terapia fotodinámica, fotosensibilizadores, porfirinas no simétricas, apoptosis, agentes anticancerígenos.

of ${ }^{1} \mathrm{O}_{2}(<0.04$ microseconds) and its limited range of action $(<0.02 \mu \mathrm{m})$, the tissue damage is closely related to the location of the PSs. Most photosensitizers are selectively localized intracellularly in the lysosomes, membranes and mitochondria. In particular, injury to mitochondria is one of the most significant forms of damage in photodynamic therapy that may cause programmed cell death (apoptosis), allowing the release of cytochrome $\mathrm{C}$ and other mitochondrial factors into the cytosol that is also known to trigger apoptosis [10]. Changes induced in the plasma membrane and membranes of cellular organelles by photodynamic therapy can trigger far-reaching effects [11].

The mechanisms by which PSs are preferentially distributed to cancer cells are not fully understood. It is believed that the properties of tumor tissue can contribute to this selectivity, including the slightly acidic interstitial fluid due to the presence of lactic acid, the abnormal structure of tumor stroma characterized by a large interstitial space, cracking of the vascular system, lymphatic drainage being engaged, a large amount of collagen (which can bind PSs) and lipids [11, 12].

Since 1978, hematoporphyrin derivatives have been used as cancer therapy for skin tumors [13]; after 10 years, McCaughan $[14,15]$ extended its application to neoplasia in the 
esophagus, head, neck, prostate and breast, among others. One decade later, Photofrin ${ }^{\circledR}$, a combination of dihematoporphyrin esters, was approved in Canada to treat bladder cancer. Three years later, Photofrin ${ }^{\circledR}$ was approved in the United States to treat obstructive esophagus neoplasia. Disadvantages of this kind of PSs include its high skin photosensitivity, low selectivity and reduced phototoxic activity. Second-generation PSs have arisen with improved selectivity, higher cytotoxic effects and lower skin photosensitivity. Nowadays, it is known that localization and nature of substituents in the $\beta$ and meso position on porphyrins are effective in their spectral, photophysical and biological characteristics [16]. In the present study, we describe the synthesis, characterization, phototoxic effects and intrinsic cytotoxicity of a unsymmetrical $\mathrm{A}_{3} \mathrm{~B}$ porphyrin, 5,10,15-Tris( $p$-chlorophenyl)-20-(2-hydroxy-3-methoxyphenyl)-21H,23H-porphyrin, as well as the induction of apoptosis after treatment with this second-generation PS. This kind of new PS exhibits less skin photosensitivity, chemically purity, exceptional stability and the ability of absorb light around 650 $\mathrm{nm}$. The porphyrin structure synthesized in this work has different groups in the meso position, in order to evaluate the synergistic effect on the phototoxicity, cellular uptake and cellular localization of hydrophobic and hydrophilic groups in asymmetric position on the porphyrin macrocycle. Phototoxicity, intrinsic cytotoxicity and induction of apoptosis were determined in HeLa cells.

\section{Results and Discussion}

The compound 5,10,15-Tris( $p$-chlorophenyl)-20-(2-hydroxy3-methoxyphenyl)-21H,23H-porphyrin was synthesized based on the assumption that meso-substituted porphyrins bearing different groups at the phenyls and a unsymmetric distribution of these groups would affect the hydrophobic/hydrophilic character of the PSs, a feature that is crucial for cell penetration and subcellular localization [17]. Previous report compared the cytotoxic activity of porphyrins substituted at meso position with hydroxyl and methoxyl groups, showing better results in hydroxy meso-substituted porphyrins, perhaps methoxy-substituted porphyrins also yielded good results [18]. Additionally, halogenated tetrapyrrolic compounds have been considered as potential photosensitizers and their structure also present other groups on meso positions allowing for an amphiphilic character $[19,20]$. The structure of the synthesized porphyrin presents different groups at the meso position, $p$-chlorophenyl and 2hydroxy-3-methoxyphenyl and is a novel target molecule to evaluate the synergistic effect of these hydrophobic and hydrophilic moieties distributed unsymmetrically on the porphyrin macrocycle.

The synthesis of the unsymmetrical porphyrin 1 (Scheme 1), was accomplished following the procedure described by Lindsey and co-workers [21] via acid-catalyzed condensation of pyrrole with two aromatic aldehydes (4-chlorobenzaldehyde and $o$-vainillin). After the first step, the porphyrinogen intermediate was formed and then oxidized to porphyrin $\mathbf{1}$

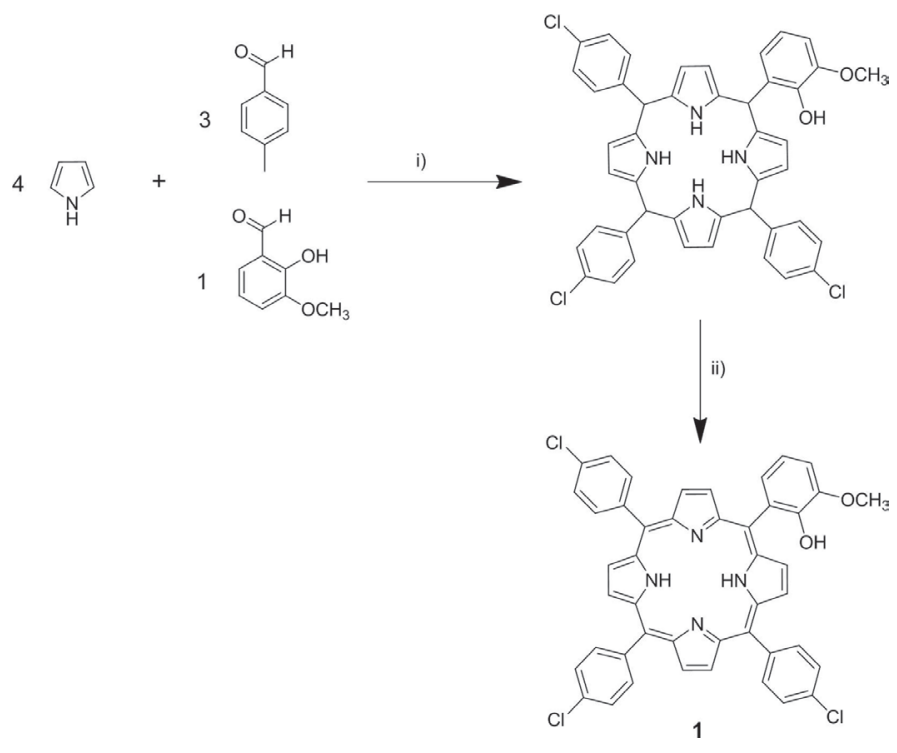

Scheme 1. Synthesis of unsymmetrical porphyrin. Reaction conditions: i) $\mathrm{TFA} / \mathrm{BF}_{3} \bullet \mathrm{O}(\mathrm{Et})_{2}, \mathrm{CH}_{2} \mathrm{Cl}_{2}, \mathrm{rt}, 2 \mathrm{~h}$; ii) DDQ, rt, $2 \mathrm{~h}$.

with 2,3-Dichloro-5,6-dicyano-1,4-benzoquinone (DDQ). The purification of this reaction mixture by column chromatography allowed us to obtain a new unsymmetrical porphyrin $\mathbf{1}$ (17.8\% yield). Chemical yields reported for unsymmetrical porphyrins by the Lindsey method are typically about $20 \%$; Whang et al. reported yields of $15 \%$ and $10 \%$ for a couple of tetraarylporphyrins [22] and other studies reported yields of $35 \%$ [23] and 22\% [24] following this method. The structure of the obtained porphyrin was confirmed by nuclear magnetic resonance (NMR), ultraviolet-visible (UV-Vis) spectroscopy, mass spectrometry (MS) and elemental analysis (EA). First, the formation of the porphyrin macrocycle was supported by UV-Vis spectroscopy; the electronic absorption spectrum contains a single intense maximum attributed to the Soret band at $405 \mathrm{~nm}$ and four Q-bands: Qy $(1,0), \operatorname{Qy}(0,0)$, Qx $(1,0)$ and $\mathrm{Qx}(0,0)$ showing much smaller absorption intensities, between 500 and $650 \mathrm{~nm}$, characteristic of the tetra-meso-substituted porphyrin chromophore in the visible region [4]. The mass spectrum showed the molecular ion peak at $\mathrm{m} / \mathrm{z} 764[\mathrm{M}]^{+}$. The ${ }^{1} \mathrm{H}$ NMR spectrum of the porphyrin 1 shows a highly shielded peak around $-2.81 \mathrm{ppm}$ corresponding to the protons of the $\mathrm{N}-\mathrm{H}$ groups in the porphyrin core and peaks at $4.11 \mathrm{ppm}$ and $5.81 \mathrm{ppm}$ corresponding to the methoxyl and hydroxyl groups, respectively. The spectrum furthermore shows well resolved signals of the aromatic protons at 7.22-7.62 ppm corresponding to the protons of the 2-hydroxy-3-methoxyphenyl group, 7.70 and $8.10 \mathrm{ppm}$ corresponding to the protons of $p$-chlorophenyl groups and finally two peaks at 8.81 and $8.90 \mathrm{ppm}$ corresponding to the $\beta$-protons of the pyrrole rings. The integration ratio of all signals corresponds to the expected for the different protons of the synthesized molecule.

The results of phototoxicity and intrinsic cytotoxicity of the unsymmetrical porphyrin $\mathbf{1}$ on HeLa cells are presented in percentages of viability (Table 1). Figure 1 shows the dose- 
Table 1. Percentages of viability values ${ }^{\mathrm{a}}$ of phototoxicity and intrinsic cytotoxicity of the unsymmetrical porphyrin $\mathrm{A}_{3} \mathrm{~B}$ NS1 on Hela cells.

\begin{tabular}{ccc}
\hline$\mu \mathrm{M}$ & $\begin{array}{c}\text { phototoxicity } \\
(\text { viability } \% \pm \mathrm{SD})\end{array}$ & $\begin{array}{c}\text { intrinsic cytotoxicity } \\
\text { (viability } \% \pm \mathrm{SD})\end{array}$ \\
\hline 13 & $7.1 \pm 1.1$ & $9.6 \pm 2.3$ \\
6.5 & $14.4 \pm 5.1$ & $67.7 \pm 5.2$ \\
1.3 & $55.2 \pm 5.9$ & $84.1 \pm 5.2$ \\
0.13 & $94.4 \pm 12.1$ & $90.1 \pm 13.7$ \\
0.013 & $95.5 \pm 8.7$ & $93.5 \pm 3.9$ \\
\hline
\end{tabular}

a Percentages of viability values are reported as means of three independent experiments \pm SD (standard deviation).

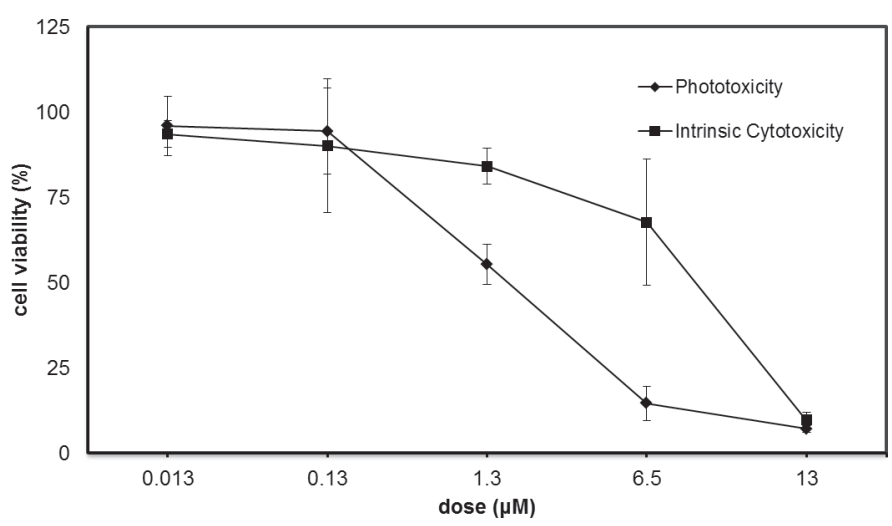

Fig. 1 Phototoxicity dose-response curve obtained in Hela cells following exposure to porphyrin 1 for $24 \mathrm{~h}$ and irradiation with visible light for $2 \mathrm{~h}$. The intrinsic cytotoxicity obtained as described above, but omitting the light irradiation. The colorimetric WST-1 test was used for cell death estimation.

response curves obtained in HeLa cells following exposure to the unsymmetrical porphyrin $\mathbf{1}$ for $24 \mathrm{~h}$ and further irradiation with visible light for $2 \mathrm{~h}$ (phototoxicity) and also by omitting the irradiation step (intrinsic cytotoxicity). Phototoxicity and intrinsic cytotoxicity curves show similar values of cytotoxicity at porphyrin 1 concentration of 0.013 and $0.13 \mu \mathrm{M}$, while at concentration of $6.5 \mu \mathrm{M}$, the phototoxicity has a viability percentage of 14.4 and intrinsic cytotoxicity has a viability percentage of 67.7, showing a marked difference in cytotoxic activity. The highest concentration of porphyrin 1 dissolvent $(0.5 \%$ dichloromethane in minimum essential medium (MEM)) was non-toxic. Phototoxicity and intrinsic cytotoxicity values were used to calculate the $\mathrm{IC}_{50}$ and a considerable difference was found: $1.5 \mu \mathrm{M}$ for phototoxicity and $7 \mu \mathrm{M}$ for intrinsic cytotoxicity. This difference is in agreement with the main requirements of the cytotoxic activity of a PS, which needs to be active in the presence of irradiation and inactive in the absence of light, thereby reducing side effects.

The results of phototoxicity presented here are similar to other studies where synthesized porphyrins were tested in different cell lines. In a study reported in 2006 by Banfi et al. [17], seven meso-tetrarylporphyrins were synthesized and exhibited $\mathrm{IC}_{50}$ values between 0.053 and $1.8 \mu \mathrm{M}$; these authors compared its phototoxic effects against temoporfin $\left(\mathrm{IC}_{50}=0.0057 \mu \mathrm{M}\right)$ in HCT 116 cells (colorectal carcinoma). The porphyrin 1 presented here shows similar phototoxic effect $\left(\mathrm{IC}_{50}=1.5 \mu \mathrm{M}\right)$ compared with this study. On other hand, in a study presented in 2012 by Banerjee et al. [25], Photofrin ${ }^{\circledR}$ shows an $\mathrm{IC}_{50}$ value of $4.3 \mu \mathrm{M}$ in HeLa cells; accordingly with these data, porphyrin 1 is more phototoxic than Photofrin ${ }^{\circledR}$. The intrinsic cytotoxicity profile observed in this study shows a similar behavior to that presented by Cheng-Liang et al. [8] in 2008.

Apoptosis requires transcriptional specific gene activation, including activation of endonucleases, DNA degradation and activation of caspases [26]. The apoptotic index was determined by T.U.N.E.L. assay. One of the major characteristics of apoptosis is the degradation of DNA after the activation of $\mathrm{Ca}^{2+} / \mathrm{Mg}^{2+}$-dependent endonucleases. This DNA cleavage leads to strand breaks within the DNA. The T.U.N.E.L. method identifies cells with DNA strand breaks detected by the activity of the terminal deoxynucelotidyl transferase, an enzyme that catalyzes the addition of dUTPs. Those nucleotides are previously labeled, allowing for the detection of apoptotic cells by a developing color assay with streptavidin-biotin-peroxidase substrate. HeLa cells treated with the unsymmetrical porphyrin 1 to a final concentration of $80 \mu \mathrm{M}$ showed $15 \%$ apoptotic cells, whereas the control showed only $2.5 \%$, which indicates the significant presence of apoptosis in treated cells compared with the control (Figure 2). Figure 3A shows the control cells where viable cells can be microscopically observed and apoptotic cells that were treated with unsymmetrical porphyrin 1 for $24 \mathrm{~h}$ and further irradiated with visible light for $2 \mathrm{~h}$ are shown in Figure 3B.

Some studies have documented the presence of apoptosis generated by the treatment of similar PSs. A work introduced in 2004 by Banfi et al. [18] shows that meso-tetrarylporphyrins induced cell death mainly by apoptosis in HCT 116 cells, confirming the results obtained in this study, which also are in agreement with observations reported by other authors [27-29]. Cells in apoptosis are characterized by cell shrinkage; meanwhile organelles and plasma membrane retain their integrity over a long period and the cells are ultimately fragmented

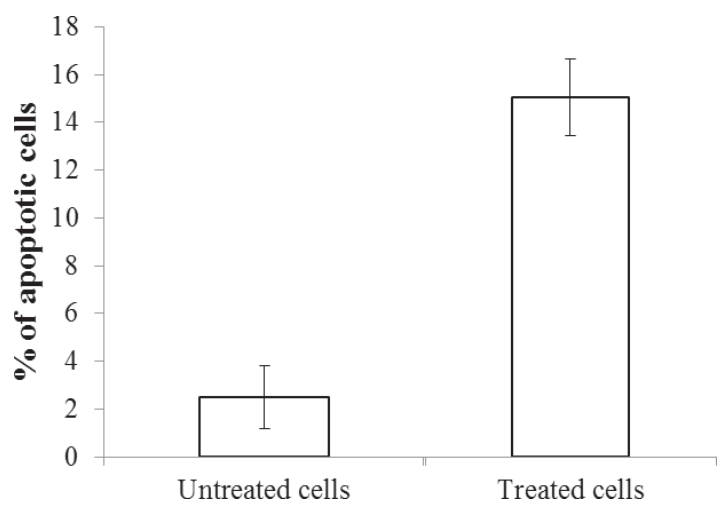

Fig. 2 Determination of apoptotic index of unsymmetrical porphyrin 1 in HeLa cells following exposure to porphyrin for $24 \mathrm{~h}$ and irradiation with visible light for $2 \mathrm{~h}$, the control cells were not irradiated. 


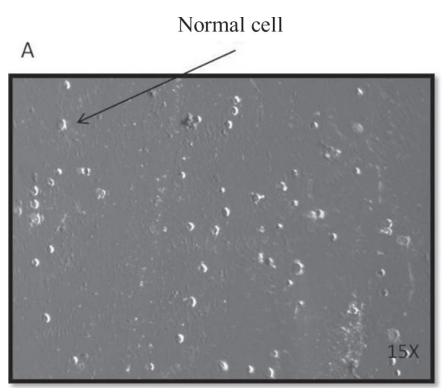

Untreated cells

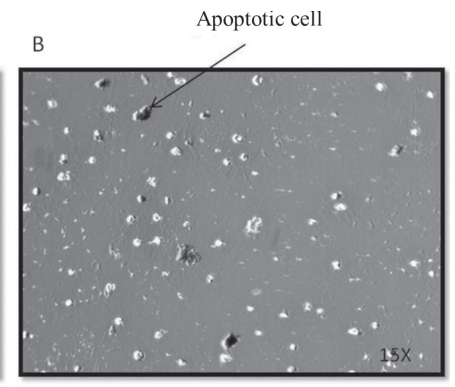

Treated cells
Fig. 3 Microscope photographs after determining the apoptotic index by TUNEL. Panel A shows untreated cells and panel B shows the cells treated with the unsymmetrical porphyrin $\mathbf{1}$.

into apoptotic bodies, which are ingested by phagocytes, thereby preventing inflammation.

\section{Conclusions}

We have accomplished the synthesis and characterization of 5,10,15-Tris( $p$-chlorophenyl)-20-(2-hydroxy-3-methoxyphenyl) $21 \mathrm{H}, 23 \mathrm{H}$-porphyrin, evaluated its phototoxic activity and the induction of apoptosis. We found that this compound was more active than Photofrin ${ }^{\circledR}$ and similar to other meso-tetrarylporphyrins. These results allowed us to consider porphyrin $\mathbf{1}$ as a potential photosensitizer in photodynamic therapy due to the structural synergistic effect of the hydrophobic and hydrophilic groups distributed unsymmetrically on the porphyrin macrocycle.

\section{Experimental}

The aromatic aldehydes were purchased from Sigma-Aldrich ${ }^{\circledR}$ (México). Pyrrole was distilled just before use. Dichloromethane, used as a reaction solvent, was distilled from $\mathrm{LiAlH}_{4}$ directly into the reaction flask. Analytical thin-layer chromatography (TLC) was performed on Merck 60 F254 silica gel. Silica gel 60 (230-400 mesh, Merck) was used for column chromatography. The UV-vis absorption spectra were measured on a Perkin Elmer Lambda 12 spectrophotometer. NMR spectra were measured in $\mathrm{CDCl}_{3}$ on a Varian-NMR System $500 \mathrm{MHz}$ spectrometer. Mass spectrometric measurements were performed on a JEOL JMS700 instrument. Elemental analysis was performed on a CHNS/O Perkin Elmer 2400 analyzer.

\section{Synthesis and characterization of 5,10,15-Tris( $p$ - chlorophenyl)-20-(2-hydroxy-3-methoxyphenyl)-21H,23H- porphyrin 1}

$\mathrm{BF}_{3} \cdot \mathrm{O}(\mathrm{Et})_{2}(0.012 \mathrm{mmol})$ and trifluoroacetic acid (TFA) $(0.35$ $\mathrm{ml}, 0.45 \mathrm{mmol})$ were added to a solution of $0.5266 \mathrm{~g}(3.75$ $\mathrm{mmol})$ of 4-chlorobenzaldehyde, $0.1902 \mathrm{~g}(1.25 \mathrm{mmol})$ of 2 hydroxy-3-methoxybenzaldehyde and $0.35 \mathrm{ml}(5 \mathrm{mmol})$ of freshly distilled pyrrole in $300 \mathrm{~mL}$ of $\mathrm{CH}_{2} \mathrm{Cl}_{2}$; the mixture was kept at room temperature for $2 \mathrm{~h}$. Next, $0.570 \mathrm{~g}(0.251 \mathrm{mmol})$ of DDQ was added and the mixture was kept at room temperature for $2 \mathrm{~h}$. The solvent was evaporated and the raw material was purified by column chromatography $\left(\mathrm{SiO}_{2} ; \mathrm{CH}_{2} \mathrm{Cl}_{2}\right)$. Porphyrin 1 (yield $17.8 \%$ ) was obtained as a purple solid. UV-Vis $\left(\mathrm{CH}_{2} \mathrm{Cl}_{2}\right): 405,514,548,589$ and $645 \mathrm{~nm} ;{ }^{1} \mathrm{H}$ NMR $(500 \mathrm{MHz}$, $\left.\mathrm{CDCl}_{3}\right): \delta-2.81(2 \mathrm{H}, \mathrm{s}$, pyrrole-NH), $4.11(3 \mathrm{H}, \mathrm{s},-\mathrm{OCH} 3), 5.81$ $(1 \mathrm{H}, \mathrm{s},-\mathrm{OH}), 7.22(1 \mathrm{H}, \mathrm{d}, \mathrm{J}=8.2 \mathrm{~Hz}, \mathrm{Ph}), 7.29(1 \mathrm{H}, \mathrm{d}, \mathrm{J}=8.2$ $\mathrm{Hz}, \mathrm{Ph}), 7.62(1 \mathrm{H}, \mathrm{t}, \mathrm{J}=7.2 \mathrm{~Hz}, \mathrm{Ph}), 7.70(6 \mathrm{H}, \mathrm{d}, \mathrm{J}=7.8 \mathrm{~Hz}, \mathrm{Ph})$, $8.10(6 \mathrm{H}, \mathrm{d}, \mathrm{J}=6.3 \mathrm{~Hz}, \mathrm{Ph}), 8.81(6 \mathrm{H}, \mathrm{s}$, pyrrole-H), $8.90(2 \mathrm{H}, \mathrm{d}$, $\mathrm{J}=4.4 \mathrm{~Hz}$, pyrrole-H)-, ${ }^{13} \mathrm{C}$ NMR $\left(126 \mathrm{MHz}, \mathrm{CDCl}_{3}\right): \delta 146.42$, $145.95,140.53,140.48,135.48,134.29,134.25,128.04,127.94$, 126.96, 118.93, 118.67, 118.32, 115.04, 110.95, 56.28; MS: m/ z $764\left[\mathrm{M}^{+}\right]$; Anal. C $70.56 \%$; H $3.88 \%$, N $7.12 \%$; calculated for $\mathrm{C}_{45} \mathrm{H}_{29} \mathrm{Cl}_{3} \mathrm{~N}_{4} \mathrm{O}_{2}, \mathrm{C} 70.73 \%$; $\mathrm{H} 3.83 \%$; N $7.33 \%$.

\section{Cytotoxicity studies}

The cytotoxic effects of the 5,10,15-Tris(p-chlorophenyl)20(2-hydroxy,3-methoxyphenyl)-21H,23H-porphyrin on human adenocarcinoma HeLa cells (ATCC: CL-2) maintained in MEM supplemented with $10 \%$ fetal bovine serum at $37^{\circ} \mathrm{C}$ in a humidified 5\% $\mathrm{CO}_{2}$ atmosphere, were assessed using the WST1 assay. Briefly, $5 \times 10^{3}$ cells were seeded on to 96-well plates and incubated for $24 \mathrm{~h}$ to grow. After this incubation period, the cells were treated with different concentrations of the compound (porphyrin was first dissolved in $50 \mu 1$ of dichloromethane and then diluted in MEM medium to raise a stock concentration of $130 \mu \mathrm{M}$; the final concentration of dichloromethane in each reaction well was $0.5 \% \mathrm{v} / \mathrm{v}$ or less) and incubated for 24 h. Later, the medium was replaced by PBS and the cells were irradiated under visible light (LED Lamp ATLED Apollo BR40 $35 \mathrm{~W}$ true white, $0.3 \mathrm{~m}$ away from the culture plate) for $2 \mathrm{~h}$. At the end of this time, the cells were incubated for $24 \mathrm{~h}$; WST-1 was then added to each well $(10 \mu \mathrm{L})$ for $2 \mathrm{~h}$ at $37^{\circ} \mathrm{C}$. Optical densities were measured at $450 \mathrm{~nm}$ using a Universal Microplate Reader ELx800 (Biotek Instrument, Vermont, USA). The intrinsic cytotoxic effects of the porphyrin were assessed as described above, but omitting cell irradiation $[18,30]$. Triton X$100,1 \%$ was used as a control of $0 \%$ viability; non-treated cells were used as a control of $100 \%$ viability.

\section{Apoptotic index}

T.U.N.E.L. assays were carried out using a DeadEnd ${ }^{\mathrm{TM}}$ Colorimetric T.U.N.E.L. System (Promega, WI, USA). The treated and untreated cells were attached to poly (L-lysine)-coated glass-bottomed dishes and fixed for $30 \mathrm{~min}$ in $4 \%$ paraformaldehyde in PBS (pH 7.4). After the cells were washed three times with PBS, the endogenous peroxidase was inactivated by incubation with $3 \% \mathrm{H}_{2} \mathrm{O}_{2}$ in methanol for $30 \mathrm{~min}$ at room temperature. The cells were again washed with PBS and subsequently permeabilized for 2 min on ice with $0.1 \%$ Triton X100. After two PBS washing steps, the cells were labeled with the biotinylated nucleotides for $60 \mathrm{~min}$ at $37^{\circ} \mathrm{C}$, washed and 
stained with peroxidase-streptavidin-biotin for $30 \mathrm{~min}$ at $37^{\circ} \mathrm{C}$. DNA fragmentation was detected by developing dark brown color with diaminobenzidine substrate and observed under light microscope (Leica, IL, USA) [31].

\section{Acknowledgments}

The authors thank Raymundo Lizcano for his technical support. E. Arredondo also thanks CONACYT for the Postgraduate scholarship 228173.

\section{References}

1. Zhu, T. C.; Finlay J. C. Med. Phys. 2008, 35, 3127-3136.

2. Triesscheijn, M.; Baas, P.; Schellens J.; Stewart F. Oncologist. 2006, 11, 1034-1045.

3. Castano, A. P.; Mroz, P.; Hamblin, M. R. Nat. Rev. Cancer. 2006, 6, 535-545.

4. Milgrom, L.R., in: The colours of life. An introduction to the chemistry of porphyrins and related compounds, vol. 9, Ed., Oxford University Press: Oxford, 1997, 225.

5. Senge, M. O. Acc. Chem. Res., 2005, 38, 733-743.

6. Machado, A.; Gomes, W.R.; Araújo, D.M.; Miglio, H.S.; Ueno, L.T.; De Paula, R.; Cavaleiro J.A.; Newton, B.N. Molecules, 2011, $16,5807-5821$.

7. Calzavara-Pinton, P.G.; Venturini, M.; Sala, R. J. Eur. Acad. Dermatol. Venereol. 2007, 21, 293-302.

8. Cheng-Liang, P.; Ping-Shan, L.; Ming-Jium, S. Biomed. Eng-App. Bas. C. 2008, 20, 9-17.

9. O’Connor, A. E.; Gallagher, W. M.; Byrne, A. T. Photochem. Photobiol. 2009, 85, 1053-174.

10. Agostinis, P.; Berg, K.; Cengel, K.; Foster, T.; Girotti, A.; Gollnick, S.O.; Hahn, S.M; Hamblin, M.R; Juzeniene, A.; Kessel, D.; Korbelik, M.; Moan, J.; Pawel, M.; Nowis, D.; Piette, J.; Wilson, B.C; Golab, J. C.A. Cancer J. Clin. 2011, 61, 250-281.

11. Dougherty, T. J.; Gomer, C. J; Henderson, B. W.; Jori, G.; Kessel, D.; Korbelik, M.; Moan, J.; Peng, Q. J. Natl. Cancer. Inst. 1998, 90, 889-905.

12. Webber, J.; Herman, M.; Kessel, D.; Fromm, D. Ann Surg. 1999, $230,12-23$
13. Dougherty, T. J.; Kaufman, J.E.; Goldfarb, A.; Weishaupt, K.R; Boyle, D.; Mittleman, A. Cancer Res. 1978, 38, 2628-2635.

14. McCaughan, J.; Guy J.; Hawley, P.; Hicks, W.; Inglis, W.; Laufman, L.; May, E.; Nims, T.A.; Sherman, A. Lasers Surg. Med. 1983, 3, 199-209.

15. McCaughan, J.; Hicks, W.; Laufman, L. Cancer 1984, 54, $2905-$ 2910.

16. Wiedmann, M. W.; Caca, K. Curr. Pharm. Biotechnol. 2004, 5, 397-408.

17. Banfi, S.; Caruso, E.; Buccafurni, L.; Murano, M.; Monti, E.; Gariboldi, M.; Papa E.; Gramatica, P. J. Med. Chem. 2006, 49, 3293-3304.

18. Banfi, S.; Caruso, E.; Caprioli, S.; Mazzagatti, L.; Canti, G.; Ravizza, R.; Gariboldi, M.; Monti, E. Bioorg. Med. Chem. 2004, 12, 4853-4860

19. Łopuszyńska, B.; Piechocka, K.; Mikus, A.; Ostrysz, S.; Ostrowski, S. Macroheterocycles. 2013, 6, 245-250

20. Nifiatis, F.; Athas, J. C.; Gunaratne, K. D. D.; Gurung, Y.; Monette, K.M.; Shivokevich, P.J. The Open Spectroscopy Journal 2011, $5,1-12$

21. Lindsey, J. S.; Schreiman, I. C; Hsu, H. C.; Kearney, P. C.; Marguerettaz, A. M. J. Org. Chem. 1987, 52, 827-836.

22. Wang, C.; Yang, G.; Li, J.; Mele, G.; S1 ota, R.; Broda, M.; Duan, M.; Vasapollo, G.; Zhang, X.; Zhang, F. Dyes Pigm. 2009, 80, 321-328.

23. Milanesio, M. E.; Alvarez, M. G.; Yslas, E. I.; Borsarelli, C. D.; Silber, J. J.; Rivarola, V.; Durantini, E. N. Photochem. Photobiol. 2001, 74, 14-21.

24. Azenha, E. G.; Serra, A. C.; Pineiro, M.; Pereira, M. M.; Melo, J. S.; Arnaut, L.; Formosinho, S. J.; Rocha, A. M. d'A. Chem. Phys. 2002, 280, 177-190.

25. Barnajje, S.; Prasad, P.; Hussain, A.; Khan, I.; Kondaiah, P.; Chakravarty, A. R. Chem. Commun. 2012, 48, 7702-7704.

26. Mroz, P.; Yaroslavsky, A.; Kharkwal, G. B.; Hamblin, M. R. Cancers. 2011, 3, 2516-2539.

27. Wawrzynska, M.; Kałas, W.; Biały, D.; Zioło, E.; Arkowski, J.; Mazurek, W.; Strządala, L. Arch. Immunol. Ther. Exp. 2010, 58, 67-75.

28. Králová, J.; Bříza, T.; Moserová, I.; Dolenský, B.; Vašek, P.; Poučkova, P.; Kejik, Z.; Kaplanek, R.; Martasek, P.; Dvořak, M.; Kral, V. J. Med. Chem. 2008, 51, 5964-5973.

29. Szurko, A.; Krämer-Marek, G.; Widel, M.; Ratuszna, A.; Habdas, J.; Kuś, P. Acta Biochim. Pol. 2003, 50, 1165-1174.

30. Durantini, E. N. Molecules 2001, 6, 533-539.

31. Khan, M. A. S.; Chock, P. B.; Stadtman, E. R. Proc. Natl. Acad. Sci. U.S.A. 2005, 102. 